\title{
Comparison of Cerebellar Volume Between Subjects with Bilateral Congenital Blindness and Healthy Individuals
}

\author{
Comparación del Volumen Cerebelar entre Individuos Sanos y con Ceguera Bilateral Congénita
}

\author{
Rengin Kosif; ; Bünyamin Sahin ${ }^{* * *} \&$ Safiye Gürel ${ }^{* * *}$
}

KOSIF, R.; SAHIN, B. \& GUREL, S. Comparison of cerebellar volume between subjects with bilateral congenital blindness and healthy individuals. Int. J. Morphol., 31(1):239-245, 2013.

SUMMARY: Cerebellum regulates motor control and physical coordination. It is known that when eye and hand need to be worked in combination, cerebellum is active and it provides coordination between eye and hand. Cerebellar cortex atrophy appears with dismetry and saccadic eye movement. If there is no stimulant related to vision, how cerebellum is adopted under this circumstance? In order to explore this, 27 male and 16 female volunteers with bilateral congenital blindness were compared with 35 male and 33 female healthy volunteers in this study. MR images of cross-sectional sequential cerebellum of volunteers with $1.5 \mathrm{~mm}$ thickness were realized in coronal plane. The surface area of apparent cerebellum seen in cross-sections was calculated by using Onis (Ver. 2.1) programme. Surface area data obtained by systematic randomized sampling were converted to volume by Cavalieri method. Cerebellar volume of bilateral congenital blind male was $128.15 \pm 11.11 \mathrm{~cm}^{3}$, and cerebellar volume of bilateral congenital blind female was $118.60 \pm 10.73$ $\mathrm{cm}^{3}$. Cerebellar volume for healthy men and women were $132.89 \pm 12.51 \mathrm{~cm}^{3}$ and $125.97 \pm 10.78 \mathrm{~cm}^{3}$, respectively. It was revealed that cerebellar volume for bilateral congenital blind men was smaller than that of healthy men, but this difference was not significant. On the other hand cerebellar volume of bilateral congenital blind women was significantly smaller than that of healthy women ( $\mathrm{p}<0.05$ ). No asymmetry was detected between right and left side of cerebellum in both bilateral congenital blind and healthy subjects.

KEY WORDS: Bilateral congenital blindness; Cerebellum; Volume.

\section{INTRODUCTION}

Cerebellum is the region of the brain that is related to motor control, physical coordination and balance. Recent studies have also established that it is also associated with cognition and learning (Bauer et al., 2009). Cerebellum regulates motor activity and muscle tonus and prompts cognitive behavior. In addition, it plays a key role in memory and learning in the cerebellar thalamic cortical circuit (Pierson et al., 2002).

Cerebellar cortex regulates the interruption of preplanned fast movements, and in addition, cerebellar nuclei govern the continuance of fast movements. Cerebellar cortical atrophy demonstrates itself with asymmetry in saccadic movements of the eye. It is common that eye movements are represented in the median part of the vermis in cerebellum (Kornhuber et al., 1971). Cognitive problems arise in persons with cerebellar cortical atrophy, and losses in verbal intelligence, visual-spatial ability, learning and memory and functional impairment in frontal system may additionally occur (Schmahmann, 2004). An fMRI study showed that cerebellum plays an important role in hand and eye movement coordination. In the cases that necessitate a coordination between hand and eye movements (e.g. tennis), cerebellum is activated and provides the coordination between the two organs (Miall et al., 2001). The same study also established that a decrease in cerebellar activity also reduces performance. Animal testing demonstrated that some structural changes occur in cerebellum during the development of motor skills. In animals that were taught motor skills, structural changes were established in the Purkinje cells and the molecular layer (above 10\%) (Hutchinson et al., 2003).

Volume assessment studies exist in the literature. The cerebellar volume of individuals with schizophrenia, musicians, patients with dyslexia, cerebellar volume during

\footnotetext{
* Faculty of Medicine, Department of Anatomy, Assistant Professor, Abant Izzet Baysal University, Bolu, Turkey.

** Faculty of Medicine, Department of Anatomy, Professor, Ondokuzmayis University, Samsun, Turkey.

****Faculty of Medicine, Department of Radiology, Associate Professor, Abant Izzet Baysal University, Bolu, Turkey.
} 
alcohol use and cerebellar volume of healthy individuals have all been studied previously (Hutchinson et al.; Keller et al., 2003; Laycock et al., 2008; Hill et al., 2007; Göçmen-Mas et al., 2009). In blind individuals, visual cortex and plasticity have also been studied profusely (Burton, 2003; Lambert et al., 2004). However, cerebellar volume has not been a subject of research in people with bilateralcongenital blindness. How does the cerebellum adapt itself to the absence of visual stimulants? Our study will shed light on this issue.

\section{MATERIAL AND METHOD}

Included in the study were 27 males (average age $39 \pm 12$ ) and 16 females (average age $32 \pm 10$ ) with bilateral congenital blindness. In order to make a comparison with healthy individuals, 35 males (average age $43 \pm 14$ ) and 33 females (average age 37 \pm 9 ) were also included in the study. Following an approval from the ethics committee of Abant Izzet Baysal University Faculty of Medicine, consecutive images were obtained in coronal direction with $1.5 \mathrm{~mm}$ section thickness from the volunteers by using the 1.5 Tesla Magneton Symphony model MR device made in Germany, at the Department of Radiology in our hospital (Levitt et al., 1999). Images were saved in Dicom format. Images were then viewed by using the Onis (Ver. 2.1) software. All the sections showing cerebellum from anterior towards posterior were observed. Following a windowing procedure that would distinguish cerebellum from peripheral tissues, the same software was used to measure the surface area of cerebellum that was visible in the sections. Since the number of sections was high, a sampling at every third section was conducted conforming to the systematic random sampling rules. The software could render the surface information automatically when the outlines of the cerebellum image were drawn in the sections studied by the polygon selection feature of the software. The section's surface measurement was conducted for each half individually. Borders of the cerebellum were framed after the midline was specified (Figs. 1 y 2). Images from MR sectional anatomy atlas were referred to in order to determine the border of the cerebellum (Moeller \& Reif, 2002). The obtained surface information was found by using the volume calculation formula of Cavalieri's Principle below (Sahin et al., 2008).

$$
\mathrm{V}=\mathrm{t} x \sum \mathrm{A}
$$

The $t$ in the formula represents the section in terms of $\mathrm{cm}$; the thickness of slices was $1.5 \mathrm{~cm}$ in our study. As the sampling was conducted at every third section, the thickness was specified as $4.5 \mathrm{~mm}$. SA represents the total surface area of the sections under study.

The accuracy of systematic random sampling was verified by estimating the error coefficient. To this end, the below formula was utilized:

$C E=\left(\sum_{i=1}^{n} A_{i}\right)^{-1} \times\left[\frac{1}{12}\left(3 \sum_{i=1}^{n} A_{i}^{2}-4 \sum_{i=1}^{n-1} A_{i} A_{i+1}+\sum_{i=1}^{n-2} A_{i} A_{i+2}\right)\right]^{1 / 2}$

where $\mathrm{i}=1,2, \ldots, \mathrm{m}=$ section number, $\mathrm{n}=$ number of consecutive sections, and $\mathrm{A}=$ measured area (sq.cm) (Mazonakis et al., 2002).

The obtained section surface area values were written down on the study pages created in Microsoft Excel software, and the volume and the coefficient error estimations were automatically conducted.

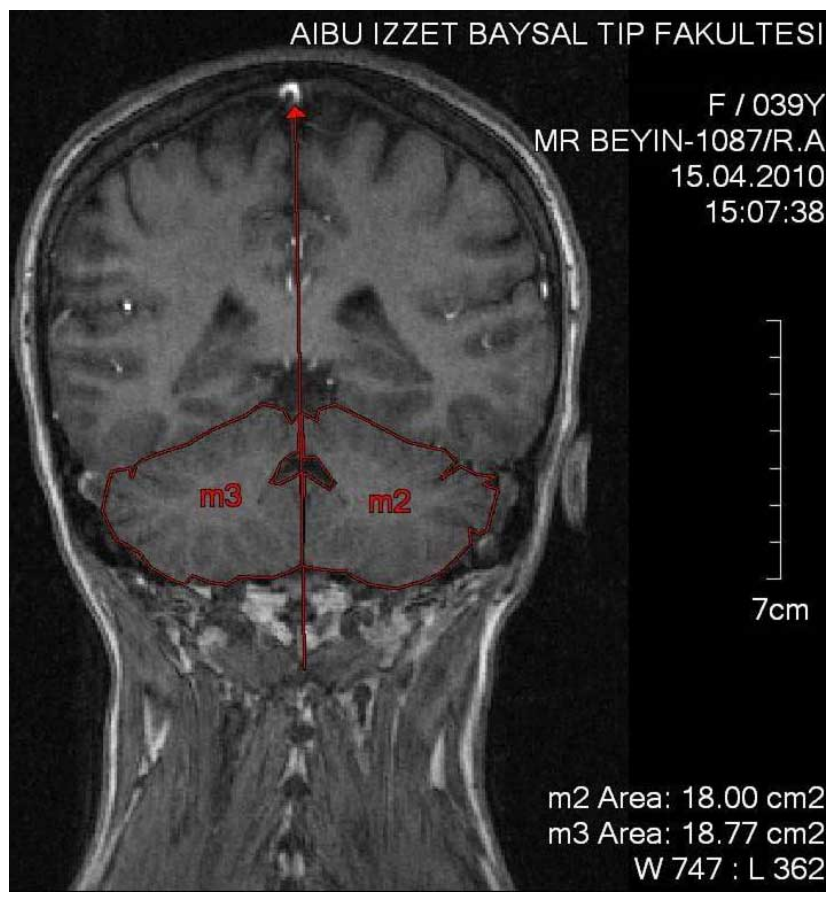

Fig. 1. Section surface area measurement with Onis 2.1 software.

Statistical comparisons were carried out by saving the volume measurements in SPSS software. Student-t test was used to compare the two groups, and $p<0.05$ was accepted as significant. The coefficient of error for each measurement was calculated. 


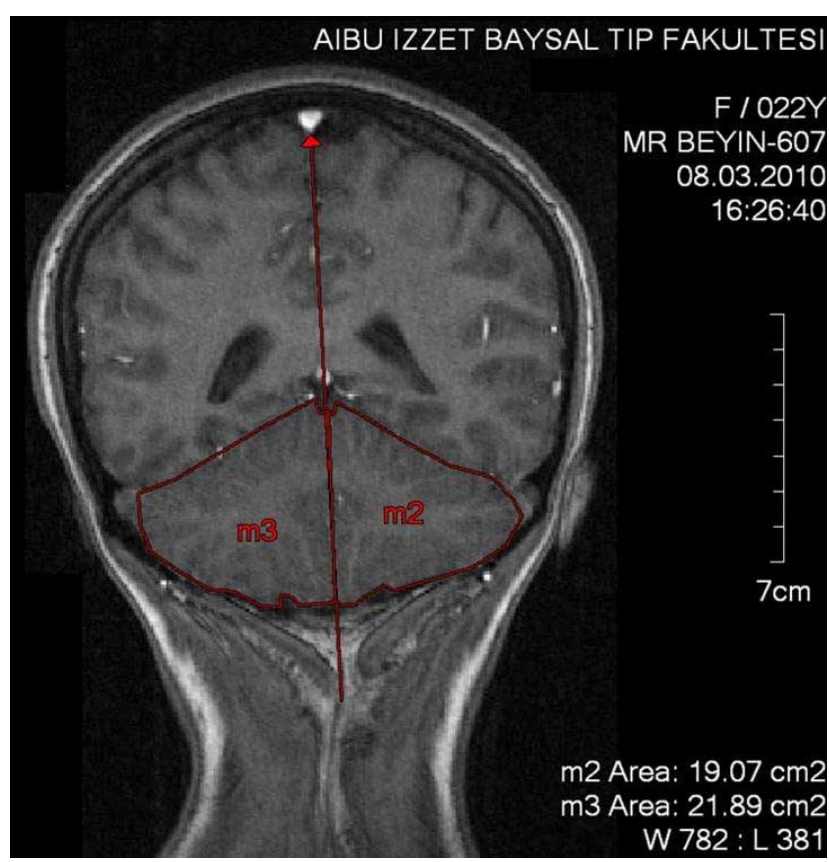

Fig. 2. Section surface area measurement with Onis 2.1 software

\section{RESULTS}

Averages of males with bilateral congenital blindness: Volume of the right lobe of cerebellum was $64.53 \pm 5.51 \mathrm{~cm}^{3}$, volume of the left lobe was $63.61 \pm 5.83 \mathrm{~cm}^{3}$, and total cerebellar volume was $128.15 \pm 11.11 \mathrm{~cm}^{3}$.

Averages of females with bilateral congenital blindness: Volume of the right lobe of cerebellum was $59.46 \pm 5.60 \mathrm{~cm}^{3}$, volume of the left lobe was $59.13 \pm 5.18 \mathrm{~cm}^{3}$, and total cerebellar volume was $118.60 \pm 10.73 \mathrm{~cm}^{3}$ (Table I).

Volume of the right lobe of cerebellum of healthy males was $67.12 \pm 6.56 \mathrm{~cm}^{3}$, volume of the left lobe was $65.78 \pm 6.28 \mathrm{~cm}^{3}$, and total cerebellar volume was $132.89 \pm 12.51 \mathrm{~cm}^{3}$. Volume of the right lobe of cerebellum of healthy females was $63.30 \pm 5.53 \mathrm{~cm}^{3}$, volume of the left lobe was $62.66 \pm 5.35 \mathrm{cc}$, and total cerebellar volume was $125.97 \pm 10.78 \mathrm{cc}$ (Table II).

The coefficient of error (\%) was calculated in the range, 0.8-1.9 for all measurements.

Measurements showed normal distributions in descriptive analyse ( $p>0.05$ ) (Fig. 3 y 4).

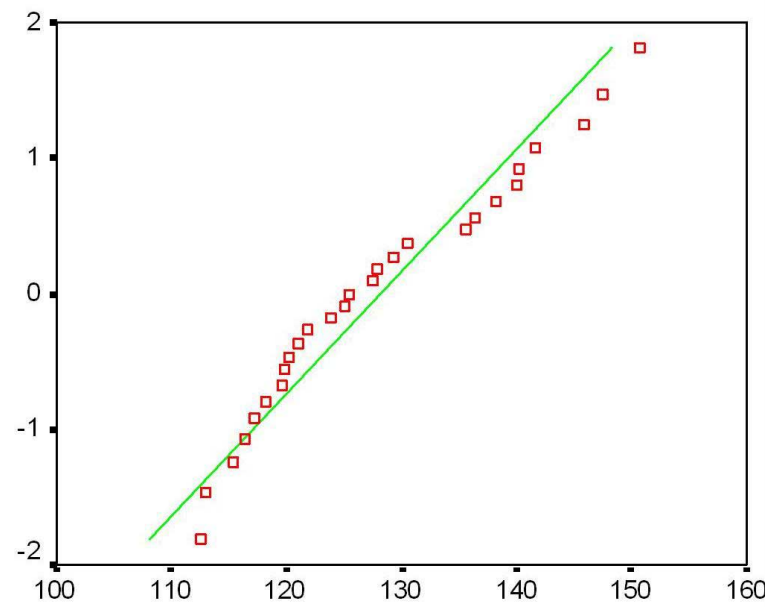

Fig. III. Normal distribution of congenital blind males.

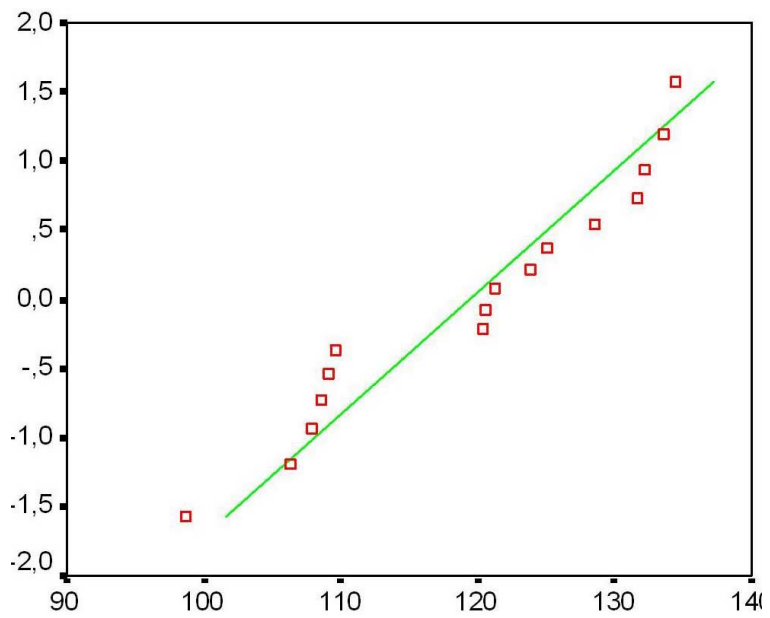

Fig. IV. Normal distribution of congenital blind females.

Table I. Average cerebellar volume of cases with bilateral congenital blindness.

\begin{tabular}{llll}
\hline & Right Side $\left(\mathrm{cm}^{3}\right)$ & Left Side $\left(\mathrm{cm}^{3}\right)$ & Total volume $\left(\mathrm{cm}^{3}\right)$ \\
\hline Male $(\mathrm{n}=27)$ & $64.53 \pm 5.51$ & $63.61 \pm 5.83$ & $128.15 \pm 11.11$ \\
Female $(\mathrm{n}=16)$ & $59.46 \pm 5.60$ & $59.13 \pm 5.18$ & $118.60 \pm 10.73$ \\
\hline
\end{tabular}

Table II. Average cerebellar volume of healthy individuals.

\begin{tabular}{llll}
\hline & Right Side $\left(\mathrm{cm}^{3}\right)$ & Left Side $\left(\mathrm{cm}^{3}\right)$ & Total volume $\left(\mathrm{cm}^{3}\right)$ \\
\hline Male $(\mathrm{n}=35)$ & $67.12 \pm 6.56$ & $65.78 \pm 6.28$ & $132.89 \pm 12.51$ \\
Female $(\mathrm{n}=33)$ & $63.30 \pm 5.53$ & $62.66 \pm 5.35$ & $125.97 \pm 10.78$ \\
\hline
\end{tabular}


ANOVA test and post-hoc Bonferroni test was performed detection of normal distribution (Tables III and IV).

When the results were compared statistically, the cerebellar volume of visually impaired males was found to be lower, but not significantly, than healthy males. In females, the cerebellar volume was established as significantly lower compared with the healthy females $(\mathrm{p}=0.03)$ (Fig. 5). Asymmetry was not observed between the right and left lobe of cerebellum in visually impaired and healthy individuals.

Table III: Anova test result.

\begin{tabular}{lrcccc}
\hline & $\begin{array}{c}\text { Sum of } \\
\text { Squares }\end{array}$ & df Mean Square & F & Sig. \\
\hline $\begin{array}{l}\text { Between } \\
\text { Groups }\end{array}$ & 96.725 & 71 & 1.362 & 1.956 & .012 \\
$\begin{array}{l}\text { Within } \\
\text { Groups }\end{array}$ & 27.167 & 39 & .697 & & \\
Total & 123.892 & 110 & & & \\
\hline
\end{tabular}

Table IV. Post-hoc test result.

\begin{tabular}{|c|c|c|c|c|c|c|c|}
\hline \multirow{2}{*}{ Bonferroni } & \multirow{2}{*}{$\begin{array}{r}\text { Group CINS } \\
1.00\end{array}$} & \multirow{2}{*}{$\begin{array}{r}\text { Group } \\
2.00\end{array}$} & \multirow{2}{*}{$\begin{array}{r}\begin{array}{r}\text { Mean } \\
\text { Difference }\end{array} \\
6.8481\end{array}$} & \multirow{2}{*}{$\begin{array}{r}\text { Std. Error } \\
2.76376\end{array}$} & \multirow{2}{*}{$\begin{array}{l}\text { Sig. } \\
\begin{array}{r}.089\end{array}\end{array}$} & \multicolumn{2}{|c|}{$\begin{array}{l}\text { Lower Upper Bound } \\
\text { Bound }\end{array}$} \\
\hline & & & & & & -.5814 & 14.2777 \\
\hline & & 3.00 & 4.7848 & 2.61809 & .422 & -2.2531 & 11.8228 \\
\hline & & 4.00 & 15.5187 & 3.25620 & .000 & 6.7654 & 24.2721 \\
\hline & 2.00 & 1.00 & -6.8481 & 2.76376 & .089 & -14.2777 & .5814 \\
\hline & & 3.00 & -2.0633 & 2.79999 & 1.000 & -9.5902 & 5.4636 \\
\hline & & 4.00 & 8.6706 & 3.40418 & .074 & -.4805 & 17.8217 \\
\hline & 3.00 & 1.00 & -4.7848 & 2.61809 & .422 & -11.8228 & 2.2531 \\
\hline & & 2.00 & 2.0633 & 2.79999 & 1.000 & -5.4636 & 9.5902 \\
\hline & & 4.00 & 10.7339 & 3.28701 & .009 & 1.8978 & 19.5700 \\
\hline & 4.00 & 1.00 & -15.5187 & 3.25620 & .000 & -24.2721 & -6.7654 \\
\hline & & 2.00 & -8.6706 & 3.40418 & .074 & -17.8217 & .4805 \\
\hline & & 3.00 & -10.7339 & 3.28701 & .009 & -19.5700 & -1.8978 \\
\hline
\end{tabular}

* The mean difference is significant at the 0.05 level.

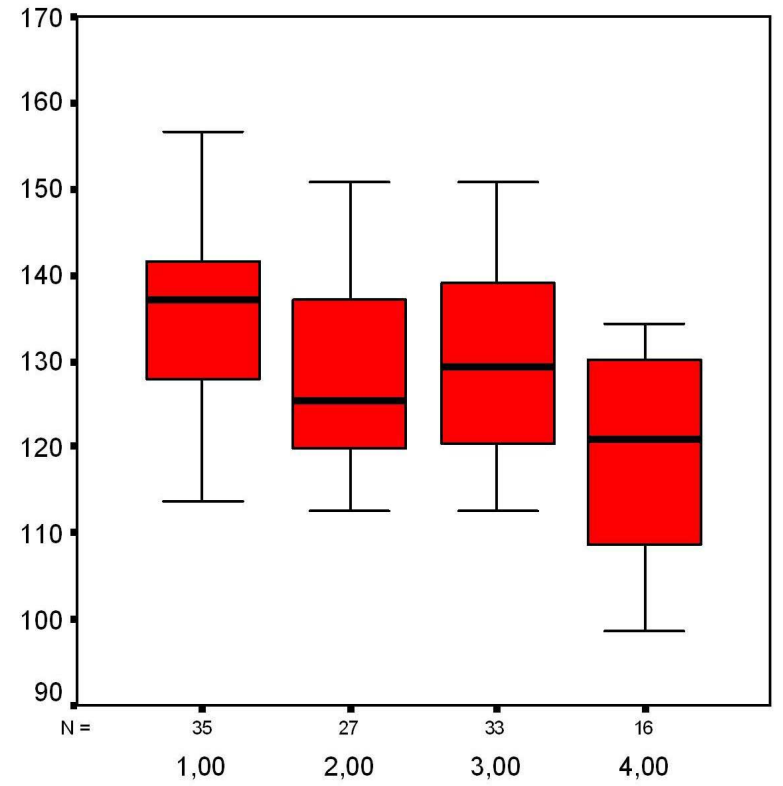

\section{DISCUSSION}

Cerebellum is an important neural component that enables coordination in walking between the joints of an extremity, two extremities, the eye and the hand, and the eye and the leg (van Donkelaar \& Lee, 1994; Vercher \& Gauthier, 1988). In his study, Miall established a significant activation increase in cerebellum in movements in which the hands and the eyes are used in combination compared with eye- or hand-only movements (Miall et $a l$.). Eye-only movements create activation in the visual cortex, parietal cortex and vermis cerebelli (Petit \& Haxby, 1999). Hand-only movements activate contralateral

Fig. V. Differences of groups. 1. Healthy males; 2. Congenitally blind males;3. Healthy females; 4. Congenitally blind females. 
sensorimotor and premotor, bilateral basal ganglion and ipsilateral cerebellum (Nishitani, 1999). It is known that slow eye movements activate Purkinje cells in cerebellar ventral paraflocculus, and this demonstrates a correlation with the acceleration of eye movements (Shidara et al., 1993). Experimental tests have shown that cerebellum is the key field in the control of adaptive eye movements (vestibulo-ocular and optokinetic reflex) (Soichi, 2000). Nucleus fastigii, flocculus, and paraflocculus are necessary for regular normal eye movements (Robinson \& Fuchs, 2001). When the inside and surface of cerebellum is stimulated in cats, horizontal, rotatory, upwards and downwards eye movements occur; it showed a reaction just as the stimulation of semicircular canals. Horizontal movements occur with the activation of tuber vermis and nucleus fastigii, and upwards and downwards eye movements happen with the activation of the median of anterior and posterior lobe and vermis. Downwards rotatory eye movements occur with the activation of the lateral regions of nodulus and uvula, and the activation of nucleus dentatus leads to upwards rotatory eye movements. It was established that eye movements are topographically arranged in cerebellum and that they have neural organization (Cohen et al., 2004).

A significant increase was observed in the response of Purkinje cells contrary to the rate of turn of the eyes and the head following motor learning. Vertical Purkinje cells demonstrate sensitivity to eye movements. Flocculus is a part of the circulation in conveying the signals of the position of the eye to motor neurons, and the occurrence of a change in Purkinje cells is not a surprise (Blazquez et al., 2003).

The brain experiences structural changes in visually impaired individuals and is re-organized by adapting to the lack of sensorial inputs. The volume of regions in the brain associated with sight was found to be smaller in visually impaired individuals compared with sighted individuals. However, the volume of the regions not related to sight was established as bigger so as to compensate this. Frontal lobes of visually impaired individuals were established as bigger compared with sighted people (Leporé et al., 2010). Regardless of whether it is congenital or acquired, the hippocampus volume of the visually impaired was found to be greater compared with healthy individuals (Fortin et al., 2008).

Early blindness causes abnormal increase in corticocortical and thalamocortical connections. This increase in connections results in thicker cerebral cortex in early blindness (predominantly 1st layer). However, the cortical surface area was established as lower (Jiang et al., 2009).
In early blindness, significant increase was observed in the blood flow of cerebellum, inferior occipital cortex and regional cerebrum (Uhl et al., 1993).

Significant decreases occur in saccadic (fast eye movements) and smooth pursuit (slow tracking movement) movements in cerebellar diseases (Ceravolo et al., 2002).

Cerebellar volume has never been studied before on individuals with bilateral congenital visual impairment.

In our study, the cerebellar volume of males and females with congenital visual impairment was found to be smaller compared with healthy individuals. This finding was statistically significant in females but not in males. The relationship between cerebellum and the eyes is intensive and complicated. Since impulses that would normally need to come from the eyes and circulations that should occur do not reach their target from birth onwards, atrophy could be expected in cerebellum due to low usage. Atrophy may occur in cerebellum due to such reasons as the absence of stimulus that would normally come from the eyes, inability to have voluntary eye movements, or inactive midways.

Asymmetry is non-existent between right and left lobes of cerebellum. Asymmetry has not been previously established in the cerebellums of blind individuals either. In line with the literature (Göçmen-Mas et al.), asymmetry was also not found in healthy individuals in our study.

Conflict of interest: This study was supported by the Abant Izzet Baysal University Scientific Research Committee.

KOSIF, R.; SAHIN, B. \& GÜREL, S. Comparación del volumen cerebelar entre individuos sanos y con ceguera bilateral congénita. Int. J. Morphol., 31(1):231-238, 2013.

RESUMEN: Cuando el ojo y la mano necesitan trabajar de manera combinada, el cerebelo se activa y proporciona la coordinación entre éstos. La atrofia de la corteza cerebelosa aparece con dismetría y movimientos oculares sacádicos. Si no hay estimulantes de la visión, ¿cómo se adapta el cerebelo en esta circunstancia? Se realizó un estudio con sujetos voluntarios, 27 hombres y 16 mujeres con ceguera congénita bilateral los cuales fueron comparados con 35 hombres y 33 mujeres sanas. Se realizó la toma de imágenes resonancia magnética, obteniendo secciones transversales del cerebelo de manera secuencial con espesor de $1,5 \mathrm{~mm}$ en el plano coronal. El área superficial aparente del cerebelo observada en las secciones ransversales se calculó mediante el uso del software Onis (Ver. 2,1). Los datos de superficie obtenidos mediante muestreo aleatorio sistemático fueron utilizados para calcular el volumen utilizando el método de Cavalieri. El volumen cerebelar bilateral de los hombres con cegera congénito fue $128,15 \pm 11,11 \mathrm{~cm} 3$ y mujeres fue $118,60 \pm 10,73$ 
cm3. Los volumenes del cerebelo en hombres y mujeres sanos fueron $132,89 \pm 12,51 \mathrm{~cm} 3$ y $125,97 \pm 10,78 \mathrm{~cm} 3$, respectivamente. Se reveló que el volumen del cerebelo de los hombres con cegera bilateral congénita fue menor que el de los hombres sanos, pero esta diferencia no fue significativa. Por otro lado el volumen del cerebelo de las mujeres con cegera bilateral congénita fue significativamente menor que el de mujeres sanas ( $p<0,05)$. No se detectó asimetría entre el lado derecho e izquierdo del cerebelo, tanto en sujetos con cegera bilateral congénita como sujetos sanos.

rebelo; Volumen.

PALABRAS CLAVE: Ceguera congénita bilateral; Ce-

REFERENCES

Bauer, P. M.; Hanson, J. L.; Pierson, R. K.; Davidson, R. J. \& Pollak, S. D. Cerebellar volume and cognitive functioning in children who experienced early deprivation. Biol. Psychiatry, 66:1100-6, 2009.

Blazquez, P. M.; Hirata, Y.; Heiney, S. A.; Gren, A. M. \& Highstein, S. M. Cerebellar signatures of vestibulo-ocular reflex motor learning. J. Neurosci., 23(30):9742-51, 2003.

Burton, H. Visual cortex activity in early and late blind people. $J$. Neurosci., 23(10):4005-11, 2003.

Ceravolo, R.; Fattori, B.; Nuti, A.; Dell'Agnello, G.; Cei, G.; Casani, A.; Naci, A.; Murri, L. \& Bonuccelli, U. Contribution of cerebellum and brainstem in the control of eye movement: evidence from a functional study in a clinical model. Acta Neurol. Scan., 105(1):32-9, 2002.

Cohen, B.; Goto, K.; Shanzer, S. \& Weiss, A. H. Eye movements induced by electric stimulation of the cerebellum in the alert cat. Exp. Neurol., 13(2):145-62, 2004.

Fortin, M.; Voss, P.; Lord C.; Lassonde, M.; Pruessner, J.; SaintAmour, D.; Rainville, C. \& Lepore, F. Wayfinding in the blind: larger hippocampal volume and supranormal spatial navigation. Brain, 131(11):2995-3005, 2008.

Göçmen-Mas, N.; Pelin, C.; Canan, S.; Yazici, A. C.; Zagyapan, R.; Senan, S.; Karabekir, H. S. \& Sahin, B. Stereological evaluation of volumetric asymmetry in healthy human cerebellum. Surg. Radiol. Anat., 31:177-81, 2009.

Hill, S.Y.; Muddasani, S.; Prasad, K.; Nutche, J.; Steinhauer, S. R.; Scanlon, J.; Mc Dermott, M. \& Keshavan, M. Cerebellar Volume in Offspring From Multiplex Alcohol Dependence Families. Biol. Psychiatry, 61(1):41-7, 2007.

Hutchinson, S.; Hui-Lin Lee, L.; Gaab N. \& Schlaug, G. Cerebellar volume of musicians. Cereb. Cortex, 13:943-9, 2003.

Jiang, J., Zhu, W., Shi, F., Liu, Y., Li J., Qin, W., Li, K., Yu, C. \&
Jiang, T. Thick visual cortex in the early blind. J. Neurosci., 29(7):2205-11, 2009.

Keller, A.; Castellanos, F. X.; Vaituzis, A. C.; Jeffries, N. O.; Giedd, J. N. \& Rapoport, J. L. Progressive loss of cerebellar volume in childhood-onset schizophrenia. Am. J. Psychiatry, 160:12833, 2003.

Kornhuber, H. H. Motor Functions of Cerebellum and Basal Ganglia: The Cerebellocortical Saccadic (Ballistic) Clock, the Cerebellonuclear Hold Regulator, and the Basal Ganglia Ramp (Voluntary Speed Smooth Movement). Biol. Cyber., 8(4):15762, 1971.

Lambert S, Sampaio E, Mauss Y, \& Scheiber C. Blindness and brain plasticity: contribution of mental imagery? An fMRI study. Brain Res. Cogn. Brain Res., 20(1):1-11, 2004.

Laycock, S. K.; Wilkinson, I. D.; Wallis, L. I.; Darwent, G.; Wonders, S. H.; Fawcett, A. J.; Griffiths, P. D. \& Nicolson, R. I. Cerebellar Volume and Cerebellar Metabolic Characteristics in Adults with Dyslexia. Ann. NY Acad. Sci., 1145: 222-236, 2008.

Leporé, N.; Vachon, P.; Lepore, F.; Chou, Y.; Voss, P.; Brun, C. C.; Lee, A. D.; Toga, A. W. \& Thompson, P. M. 3D Mapping of brain differences in native signing congenitally and prelingually deaf subjects. Hum. Brain Mapp., 31(7): 970-8, 2010.

Levitt, J. J.; McCarley, R. W.; Nestor, P. G.; Petrescu, C.; Donnino, R.; Hirayasu, Y.; Kikinis, R.; Jolesz, F. A. \& Shenton, M. E. Quantitative volumetric MRI study of the cerebellum and vermis in schizophrenia: clinical and cognitive correlates. Am. J. Psychiatry, 156(7):1105-7, 1999.

Mazonakis, M.; Damilakis, J.; Maris, T.; Prassopoulos, P. \& Gourtsoyiannis, N. J. Comparison of two volumetric techniques for estimating liver volume using magnetic resonance imaging. Magn. Reson. Imaging, 15:557-63, 2002.

Miall, R. C.; Reckess, G. Z. \& Imamizu, H. The cerebellum coordinates eye and hand tracking movements. Nat. Neurosci., 4:638-44, 2001.

Moeller T. B. \& Reif E. Pocket Atlas of Sectional Anatomy. Computed Tomography and Magnetic Resonance Imaging. Volume I, Head and Neck. $3^{\text {rd }}$ ed, Germany, 2007.

Nishitani, N. Cortical visuomotor integration during eye pursuit and eyefinger pursuit. J. Neurosci., 19:2647-57, 1999.

Pierson, R.; Corson, P. W.; Sears, L. L.; Alicata, D.; Magnotta, V.; O'Leary, D. \& Andreasen, N. C. Manual and Semiautomated Measurement of Cerebellar Subregionson MR Images. NeuroImage, 17:61-76, 2002.

Petit, L. \& Haxby, J. V. Functional anatomy of pursuit eye movements inhumans as revealed by fMRI. J. Neurophysiol, 82:463-71, 1999. 
KOSIF, R.; SAHIN, B. \& GUREL, S. Comparison of cerebellar volume between subjects with bilateral congenital blindness and healthy individuals. Int. J. Morphol., 31(1):239-245, 2013.

Sahin, B.; Mazonakis, M.; Akan, H.; Kaplan, S. \& Bek, Y. Dependence of computed tomography volume measurements upon section thickness: an application to human dry skulls. Clin. Anat., 21:479-85, 2008.

Schmahmann, J. D. Disorders of the cerebellum: ataxia, dysmetria of thought, and the cerebellar cognitive affective syndrome. $J$. Neuropsychiatry Clin. Neurosci., 16:367-78, 2004.

Shidara, M.; Kawano, K.; Gomi, H. \& Kawato, M. Inversedynamics model eye movement control by Purkinje cells in the cerebellum. Nature, 365(2):50-2, 1993.

Soichi, N. Cerebellum. Cerebellar adaptive eye movement control. Advances in Neurological Sciences, 44(5):748-59, 2000.

Robinson, F. R. \& Fuchs, A. F. The role of the cerebellum in voluntary eye movements. Annu. Rev. Neurosci., 24:981-1004, 2001.

Uhl, F., Franzen, P., Podreka, I.; Steiner, M. \& Deecke, L. Increased regional cerebral blood flow in inferior occipital cortex and cerebellum of early blind humans. Neurosci. Lett., 150(2):1624, 1993.

van Donkelaar, P. \& Lee, R. G. Interactions between the eye and hand motorsystems: disruptions due to cerebellar dysfunction. J. Neurophysiol., 72:1674-85, 1994.

Vercher, J. L. \& Gauthier G. M. Cerebellar involvement in the coordinationcontrol of the oculo-manual tracking system: effects of cerebellar dentatenucleus lesion. Exp. Brain Res., 73:155-66, 1988.
Correspondence to:

Rengin Kosif, Assistant Prof.

Abant Izzet Baysal University

Department of Anatomy Bolu

TURKEY

Tel: $+903742534656-3043$

Fax: +903742534559

E-mail: rengink@yahoo.com

Received: 02-04-2012

Accepted: 24-09-2012 